\title{
Eland browsing of Grewia occidentalis in semi-arid shrubland: the influence of bush clumps
}

\author{
L.H. WATSON
}

Watson, L.H. 1999. Eland browsing of Grewia occidentalis in semi-arid shrubland: the influence of bush clumps. Koedoe 42(1): 79-84. Pretoria. ISSN 0075-6458.

Grewia occidentalis plants in the study area generally occurred in bush clumps with other shrub species. Grewia occidentalis commonly occurred with Diospyros austroafricana, Rhus longispina and Rhus pallens (nurse shrubs), but seldom with Acacia karroo and Lycium cinereum (non-nurse shrubs). Eland browsed G. occidentalis plants at higher levels than other shrub species, but browsing was not evenly spread across all plants. Grewia occidentalis plants associated with nurse shrubs had lower levels of browsing than those growing alone and those growing with non-nurse shrubs, while $G$. occidentalis plants in the centre of nurse shrubs experienced the lowest levels of browsing. The latter group of plants also produced the most fruit. Eland browsing is considered an important factor determining the distribution of $G$. occidentalis plants in the study area, while the presence of nurse shrubs is considered essential for the establishment and maintenance of the G. occidentalis population in the study area.

Key words: Grewia occidentalis, bush clumps, eland, herbivory, semi-arid, karoo.

\section{L.H. Watson, Department of Nature Conservation, Port Elizabeth Technikon - Saasveld Campus, Private Bag X6531, George, 6530 Republic of South Africa.}

\section{Introduction}

Bush clumps formed by more than one shrub species (no distinction is made between shrubs and trees) are common in the karoo, valley bushveld and savannas of southern Africa. Bush clumps may benefit shrub species in a number of ways; clumps may act as refuges for fire sensitive species (Frost 1984); clumps may offer favourable sites for the germination of seeds; clump species may act as nurse plants and shelter seedlings from desiccation, wind and herbivory (Crawley 1997a). Bush clumps formed by two or more shrub species were common in Mountain Zebra National Park (MZNP), and G. occidentalis plants commonly grew in clumps with other shrub species. My study had two objectives: (a) to determine the distribution of $G$. occidentalis plants in relation to bush clumps and shrub species in the study area; and (b) to determine whether the distribution of $G$. occidentalis plants influenced the utilization of $G$. occidentalis by eland Taurotragus oryx.

Although eland are classified as mixed feeders (Hofmann \& Stewart 1972), browse formed $94 \%$ of the annual diet of eland in MZNP (Watson 1997). Compared to other browsers (kudu Tragelaphus strepsiceros and common duiker Sylvicapra grimmia) in MZNP, eland were the dominant browser during my study (Novellie 1989).

\section{Study area}

Mountain Zebra National Park (6536 ha) is situated $24 \mathrm{~km}$ from the town of Cradock, in the Eastern Cape Province. The vegetation of MZNP is classified as Eastern Mixed Karoo and is dominated by mesophytic grasses and dwarf shrubs (Van der Walt 1980). The veld types in MZNP after Acocks (1988) are; Karroid Merxmuellera Mountain Veld, Karroid Merxmuellera Mountain Veld replaced by Karoo Veld and False Karroid Broken Veld.

The mean annual rainfall recorded at Babylonstoren in MZNP for the period 1962-1989 was $395 \mathrm{~mm}$, while temperatures in summer may exceed $40{ }^{\circ} \mathrm{C}$ and fall below freezing in winter (Novellie 1989). The relation between bush clumps and the browsing 
of $G$. occidentalis by eland was studied in the Setaria neglecta - Acacia karroo vegetation type of the Vergesigplaat plateau (Van der Walt 1980). This vegetation type was favoured by eland during the period of study (November 1988 to January 1989) and contained high abundances of $G$. occidentalis and other shrub species (Watson 1997). Data on the acceptability of shrubs to eland were collected in a number of vegetation types used by eland during the period November 1987 to May 1989.

\section{Methods}

\section{Distribution of Grewia occidentalis plants}

To determine the frequency of occurence of $\mathrm{G}$. occidentalis as lone plants (single plants not in a bush clump) and plants in clumps, 50 plants were randomly selected in the study area and the location of each recorded. Although clumps may contain more than two shrub species, a single $G$. occidentalis plant in a clump was typically associated with a single shrub in the clump. To determine the frequency of occurence of $G$. occidentalis with other shrub species in the study area, $97 \mathrm{G}$. occidentalis plants growing in separate clumps were randomly selected in the area, and the shrub each was growing with recorded. The expected frequency of occurrence of G. occidentalis with shrub species $i$ was determined by summing the number of plants of shrub species $i$ recorded in the feeding sites $(n=24)$ used by eland in the study area (see below). This was done under the assumption that $G$. occidentalis plants occurred with shrub species $i$ in proportion to the abundance of shrub species $i$ in the study area. Shrub species which occurred with G. occidentalis more often than expected were referred to as nurse shrubs, while those which occurred with $G$. occidentalis less often than expected were referred to as non-nurse shrubs.

Because $G$. occidentalis plants growing with shrubs formed the largest proportion of $G$. occidentalis plants in the study area $(80 \%)$, these plants were used to show trends between $G$. occidentalis plants growing alone and those growing with nurse shrubs. G. occidentalis plants growing with nurse shrubs were divided into side plants (a plant growing on the side of another shrub species) and centre plants (a plant growing in the centre of another shrub species). Grewia occidentalis plants growing as lone $(n=25)$, side $(n=22)$ and centre $(n=22)$ plants were randomly selected in the study area and the following recorded; the height class of the plant; the percentage of shoots eaten from the plant (estimated using the eight point scale of Walker 1976); the number of fruit on the plant; the shrub species the plant was growing with (none for lone plants); the height class of the shrub species the plant was growing with. Surveys were done in January (1989) when G. occidentalis plants were in fruit.

\section{Acceptability and utilization of shrubs}

Acceptability indices (Owen-Smith \& Cooper 1987) were used to determine the acceptability of shrubs during the wet season (November to May) when all shrub species had leaves. The following method was used: A single adult female was fitted with a radio collar. Over the study period this animal and her companions were located 6-13 times each month and observed from a distance of 50-300 metres. The first animal seen feeding was chosen as a focal animal (Altmann 1974) and observed while feeding. To ensure that observations collected in different habitats were comparable, only feeding observations of 3-6 minutes were chosen for feeding site surveys. Two to four feeding observations were made at each location (13-28 per month). To ensure independence of observations, each feeding observation was made on a different focal animal. Although a single radio collared female was used to locate animals for observation, the size and composition of the herd associated with her varied throughout the year $($ mode $=$ $6-10$; range $=3-170$ ). Feeding observations were therefore considered representative of the eland population in the MZNP.

An assistant was directed to plants eaten by the focal animal. These plants were marked and served as indicators of the feeding path followed by the focal animal. A feeding site was designated as the area two metres on either side of the feeding path followed by the animal ( $\pm 10 \mathrm{~m}$ in length). Each feeding site was considered an independent feeding trial in which a shrub species could either be accepted (plants with fresh evidence of browsing) or rejected by the focal eland $(n=346)$. The acceptability index $\left(a i_{i}\right)$ for shrub $i$ was calculated as $a i_{i}=n_{i} / t_{i}$, where $n_{i}$ is the number of feeding sites in which shrub $i$ was accepted and $t_{i}$ is the total number of feeding sites in which shrub $i$ was recorded as available (a plant was considered available when leaves on the plant were estimated to represent $>5 \%$ of the possible leaf cover on the plant). Acceptability indices were calculated for the wet season by summing the acceptance and availability records over all months of the season.

At the end of the growing season (May 1989-July 1989), an estimate was made of the proportion of shoots eaten per plant per shrub species recorded in the feeding sites used by eland. In each feeding site surveyed $(n=48)$, a single plant from each available 
shrub species in the site was randomly selected, and the eight point scale of Walker (1976) used to estimate the percentage of shoots eaten from the plant. The mean percentage of shoots eaten per plant per species was calculated using the midpoint of each rank (Walker 1976).

\section{Statistical analysis}

The Chi-square goodness of fit test (Zar 1984) was used to test for difference in the observed and expected frequencies of occurrence of $G$. occidentalis plants with other shrub species recorded in the study area. Where appropriate the Yates correction for continuity was used.

Percentage data were arcsine transformed for statistical analysis. To test for difference across more than two groups of data, the ANOVA and the Tukey multiple comparison tests were used (Zar 1984).

\section{Results}

\section{Distribution of $\mathrm{G}$. occidentalis plants}

Of the G. occidentalis plants surveyed in the study area, $94 \%$ grew in clumps with other shrub species, while the rest grew alone. Eight shrub species other than $G$. occidentalis were recorded in feeding sites used by eland in the study area. The observed and expected frequency of occurrence of G. occidentalis with these shrubs differed significantly (Table 1). G. occidentalis was commonly associated with Diospyros austroafricana, Rhus longispina and Rhus pallens but seldom occurred with Acacia karroo and Lycium cinereum, although these were abundant in the study area (Table 1). G. occidentalis was not recorded with three shrub species which occurred in low numbers in the study area (Diospyros lycioides, Lycium oxycarpum and Maytenus heterophylla). D. austro-africana, $R$. longispina and $R$. pallens were considered nurse shrubs and $A$. karroo and $L$. cinereum non-nurse shrubs $\left(x^{2}=186.235, d f=1, P<0.0001\right)$.

\section{Acceptability and utilization of shrubs}

Acceptance values calculated during the wet season indicated that $G$. occidentalis was highly acceptable to eland, while other shrub
Table 1

The observed and expected frequencies of occurrence of $\mathrm{G}$. occidentalis plants with other shrub species $($ chi-squared $=111.770, \mathrm{df}=5, \mathrm{P}<0.0001)$

\begin{tabular}{lcc}
\hline Species & $\begin{array}{c}\text { Observed } \\
\text { frequency }\end{array}$ & $\begin{array}{c}\text { Expected } \\
\text { frequency }\end{array}$ \\
\hline $\begin{array}{l}\text { Acacia karroo Hayne } \\
\text { Lycium cinereum Thunb. }\end{array}$ & 11 & 86 \\
$\begin{array}{l}\text { Diospyros austro-africana } \\
\text { De Winter }\end{array}$ & 10 & 67 \\
$\begin{array}{l}\text { Rhus longispina } \\
\text { Eckl. \& Zeyh. }\end{array}$ & 11 & 2 \\
Rhus pallens Eckl. \& Zeyh. & 57 & 5 \\
Other' & 0 & 4 \\
\hline & 97 & 188
\end{tabular}

1 = Diospyros lycioides (Desf.) $=2 ;$ Lycium oxycarpum $($ Dun. $)=1 ;$ Maytenus heterophylla $(($ Eckl. \& Zeyh.) N.K.B. Robson) $=1$

\section{Table 2}

The percentage of shoots (mean $\pm \mathrm{SD}$ ) browsed from plants of shrub species at the end of the growing season (May-July). Percentage values were arcsine transformed for analysis. The marked mean differed significantly from the other means, while comparisons between other means are not shown $(\mathrm{F}=25.58 ; \mathrm{df}=5,99 ; \mathrm{P}<0.0001)$. $\mathrm{n}=$ number of plants

\begin{tabular}{lcc}
\hline Species & $\%$ & $n$ \\
\hline Acacia karroo & $18.8 \pm 5.8$ & 31 \\
Diospyros austro-africana & $5.4 \pm 7.4$ & 5 \\
Grewia occidentalis & $38.2^{\mathrm{a}} \pm 14.5$ & 22 \\
Lycium cinereum & $8.8 \pm 9.1$ & 9 \\
Rhus longispina & $15.2 \pm 10.0$ & 13 \\
Rhus pallens & $10.6 \pm 8.3$ & 25 \\
\end{tabular}

Table 3

The percentage of shoots (mean $\pm S D$ ) browsed from $\mathrm{G}$. occidentalis plants growing alone and with nurse shrubs and non-nurse shrubs. Percentage values were arcsine transformed for analysis. Means marked with the same letter do not differ significantly from each other $(\mathrm{F}=15.6 ; \mathrm{df}=2,72 ; \mathrm{P}<0.0001)$. $\mathrm{n}=$ number of plants

\begin{tabular}{lll}
$\begin{array}{l}\text { Alone } \\
(n=25)\end{array}$ & $\begin{array}{l}\text { Nurse shrubs } \\
(n=44)\end{array}$ & $\begin{array}{l}\text { Non-nurse shrubs } \\
(n=6)\end{array}$ \\
\hline $30.4 \pm 13.4^{\mathrm{a}}$ & $16.5 \pm 9.4$ & $34.2 \pm 14.1^{\mathrm{a}}$ \\
\hline
\end{tabular}




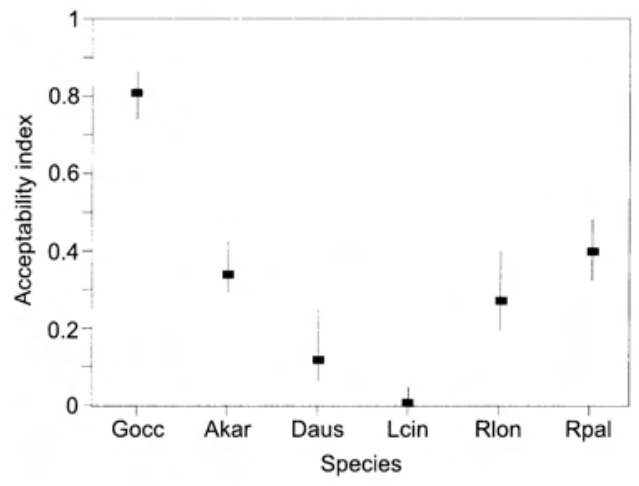

Fig. 1. Acceptability indices of shrub species to eland in the wet season (November-May). Binomial confidence intervals are indicated with vertical lines. Species codes: Gocc $=$ Grewia occi dentalis; Akar = Acacia karroo $;$ Daus = Diospyros austro-africana $;$ Lcin $=$ Lycium cinereum $;$ Rlon $=$ Rhus longispina , Rpal = Rhus pallens .

species were of low to moderate acceptability to eland (Fig. 1).

At the end of the growing season, the mean percentage of shoots browsed per plant per species differed significantly across species (Table 2). The percentage of shoots browsed from $G$. occidentalis plants was significantly higher than that browsed from any of the other species (Table 2).

\section{The influence of clumping}

The percentage of shoots browsed from $G$. occidentalis plants growing with nurse shrubs was significantly lower than that of plants growing alone and plants growing with non-nurse shrubs (Table 3 ).

The percentage of shoots browsed from $G$. occidentalis plants growing alone, and $G$. occidentalis plants growing on the sides and in the centre of nurse shrubs differed significantly. Lone plants were browsed at the highest levels and centre plants at the lowest levels (Table 4). The number of fruit on centre plants was significantly higher than that on lone and side plants, while the num- ber of fruit on the latter two groups did not differ significantly (Table 4). The height of G. occidentalis plants differed significantly between lone, side and centre groups of plants. Lone plants were the shortest and centre plants the tallest (Table 4).

The height of G. occidentalis plants growing on the sides of nurse shrubs was significantly positively correlated with the height of nurse shrubs $(r=0.814, d f=20, P<$ $0.0001)$. All centre $G$. occidentalis plants and the companion nurse shrub were $>2 \mathrm{~m}$ high.

\section{Discussion}

The Karoo is considered to be in a process of desertification, with acceptable plant species giving way to unacceptable species (Acocks 1988; Bond et al. 1994; Milton \& Dean 1995; but see Hoffman \& Cowling 1990). Over grazing/browsing of plant species is considered the primary cause of this process (Acocks 1988; Roux \& Theron 1987; Bond et al. 1994). In MZNP, G. occidentalis was highly acceptable to eland and was browsed at high levels by eland. Given the high levels of browsing and the fact that G. occidentalis plants in MZNP commonly have a hedged appearance (pers. obs.), the long term persistence of G. occidentalis in MZNP may be under threat.

Most G. occidentalis plants in the study area grew with shrub species referred to as nurse shrubs (D. austro-africana, $R$. longispina and $R$. pallens). The fruit of $G$. occidentalis is bird dispersed and this finding may indicate that $G$. occidentalis seeds were dispersed to nurse shrubs (i.e. frugivorous birds preferred the fruit/perching sites of nurse shrubs). Alternatively, nurse shrubs may have offered favourable micro sites for the germination of G. occidentalis seeds. To my knowledge neither of these aspects have been investigated. However, G. occidentalis plants growing with nurse shrubs had significantly lower levels of browsing compared to plants growing alone and plants growing with non-nurse shrubs. Heavy browsing typically lowers seedling survival 
Table 4

The percentage of shoots eaten, number of fruit on and height (mean $\pm \mathrm{SD}$ ) of $\mathrm{G}$. occidentalis plants growing alone, on the side and in the centre of nurse shrubs. For each variable means marked with the same letter do not differ significantly from each other. Percentage values were arcsine transformed for analysis. $\mathrm{n}=$ number of plants

\begin{tabular}{lcccc}
\hline & Lone $(n=25)$ & Side $(n=22)$ & Centre $(n=22)$ & $F$ \\
\hline Shoots eaten $(\%)$ & $30.4^{\mathrm{a}} \pm 13.4$ & $21.0^{\mathrm{b}} \pm 8.9$ & $12.1^{\mathrm{c}} \pm 7.8$ & $17.97 d f=2,66^{*}$ \\
Number of fruit & $3.8^{\mathrm{a}} \pm 11.7$ & $1.0^{\mathrm{a}} \pm 1.7$ & $90.0^{\mathrm{b}} \pm 60.9$ & $46.54 d f=2,66^{*}$ \\
Height $(\mathrm{m})$ & $0.5^{\mathrm{a}} \pm 0.2$ & $1.1^{\mathrm{b}} \pm 0.5$ & $2.3^{\mathrm{c}} \pm 0.0$ & $190.33 d f=2,66^{*}$
\end{tabular}

$*=P<0.0001$

(Crawley 1997b). Nurse plants however, may reduce browsing on seedlings and thus facilitate the establishment of seedlings beneath them (Crawley 1997a). I suggest that eland browsing of $G$. occidentalis was an important factor determining the distribution of $G$. occidentalis plants in the study area.

Although $G$. occidentalis plants were browsed at significantly higher levels than any of the shrubs they grew with, browsing was not evenly spread across all plants. Grewia occidentalis plants more exposed to eland herbivory (lone and side plants) were browsed at significantly higher levels than plants less exposed to eland herbivory (centre plants). Grewia occidentalis plants less exposed to eland browsing contained 20 -fold the fruit of plants more exposed to eland browsing. These plants, although only representing $11 \%$ of the G. occidentalis population in the study area, probably contributed most to the reseeding of this shrub in the area.

The mechanism of protection offered by nurse plants needs explanation. When in clumps, the leafy shoots of $G$. occidentalis typically grew amongst and through that of other shrub species. Plant spinescence is considered to act as defence against mammalian browsers (Cooper \& Owen-Smith 1986; Milewski et al. 1991), and G. occidentalis plants growing with spinescent species may benefit from the spinescence of these species. Except for $R$. longispina, nurse shrubs were non-spinescent, while both nonnurse shrubs were spinescent. Also, G. occidentalis plants growing with spinescent non- nurse shrubs had similar levels of browsing to those growing alone. Spinescence of companion shrubs is therefore not considered an important factor reducing eland browsing of $G$. occidentalis plants growing in clumps.

The growth form of nurse shrubs was typically more dense (at the ground and canopy level) than that of non-nurse shrubs. The dense growth form of nurse shrubs appeared to protect $G$. occidentalis plants from eland browsing in the following manner: (a) the dense growth form of nurse shrubs physically obstructed the access of eland to G. occidentalis plants; and (b) in MZNP, woody species favoured by eland were classified as palatable to eland, while those of low to moderate acceptability were classified as unpalatable to eland (Watson 1997). The large muzzle of eland reduces the selectivity of eland, and the dense growth of nurse shrubs appeared to restrict eland from selecting the palatable leafy shoots of G. occidentalis from among that of the unpalatable nurse shrubs.

Studies in succulent karoo indicate that due to high levels of browsing, acceptable shrubs produce less seeds than unacceptable shrubs (Milton \& Dean 1990; Milton 1994), resulting in rangelands dominated by unacceptable shrubs (Milton \& Hoffman 1994). Evidence presented here suggests that the G. occidentalis population in MZNP is under threat from eland herbivory. Evidence also indicated that clumps of nurse shrubs formed refuges for $G$. occidentalis plants against eland browsing; refuges from which reseeding could occur. Thus, under high levels of utilization, the presence of nurse shrubs is 
considered essential for the establishment and maintenance of the G. occidentalis population in MZNP.

\section{Acknowledgements}

The field work was done while registered at the University of the Witwatersrand, and I thank Prof. Norman Owen-Smith for the constructive guidance provided during this period. I thank the South African National Parks, especially Mr Ettienne Fourie, Dr Peter Novellie and the staff of Mountain Zebra National Park for their assistance and friendship during the project. $\mathrm{Mr} \mathrm{C}$. Blom of the Grootfontein Agricultural Research Institute is thanked for identifying plant specimens. The South African National Parks is thanked for the accommodation and funding provided. Comments made by Mike Cameron and Anton Schmidt on drafts of the manuscript are appreciated.

\section{References}

Acocks, J.P.H. 1988. Veld types of South Africa. Memoirs of the botanical Survey of South Africa 57: 1-146.

Altmann, J. 1974. Observational study of behaviour. Behaviour 49: 157-164.

Bond, W.J., W.D. STOCK \& M.T. HoffMan. 1994. Has the karoo spread? A test for desertification using carbon isotopes from soil. South African Journal of Science 90: 391-397.

COOPER, S.M. \& N. OWEn-SMITH. 1986. Effects of plant spinescence on large mammalian herbivores. Oecologia 68: 446-455.

CRAwley, M.J. 1997a. Life history and environment. Pp. 73-131. In: Crawley, M.J. (ed.). Plant ecology. Oxford: Blackwell.

Crawley, M.J. 1997b. Plant-herbivore dynamics. Pp. 401-474. In: Crawley, M.J. (ed.). Plant ecology. Oxford: Blackwell.

Frost, P.G.H. 1984. The responses and survival of organisms in fire-prone environments. $\mathrm{Pp}$ 273-310. In: BOOYSEN, P. DE V. \& N.M. TAINTON (eds.). Ecological effects of fire in South African ecosystems. Berlin: SpringerVerlag.

HoffMAn, M.T. \& R.M. Cowling. 1990. Vegetation change in the semi-arid eastern Karoo over the last two hundred years: an expanding Karoo-fact or fiction? South African Journal of Science 86: 286-294.
Hoffmann, R.R \& D.R.M. STEwarT. 1972. Grazer or browser: A classification based on stomach structure and feeding habits of East African ruminants. Mammalia 36: 226-240.

Milewski, A.V., T.P. Young \& A. MAdDEN. 1991. Thorns as induced defences: experimental evidence. Oecologia 86: 70-75.

MiLton, S.J. 1994. Small-scale reseeding trials in arid rangeland: Effects of rainfall, clearing and grazing on seedling survival. African Journal of Range and Forage Science 11: 54-58.

Milton, S.J. \& W.R.J. DEAN. 1990. Seed production in the rangelands of the southern Karoo. South African Journal of Science 86: 231-233.

Milton, S.J. \& W.R.J. DEAn. 1995. South Africa's arid and semi-arid rangelands: why are they changing and can they be restored? Environmental Monitoring and Assessment 37: 245-264.

Milton, S.J. \& M.T. Hoffman. 1994. The application of state-and-transition models to rangeland research and management in arid succulent and semi-arid grassy Karoo, South Africa. Journal of the Grassland Society of Southern Africa 11: 18-26.

Novellie, P.A. 1989. Management plan for the Mountain Zebra National Park. Internal report, National Parks Board of the Republic of South Africa, Pretoria.

OWen-Smith, N. \& S.M. CoOper. 1987. Assessing food preferences of ungulates by acceptability indices. Journal of Wildlife Management 51: 372-378.

ROUX, P.W. \& G.K. THERON. 1987. Vegetation change in the karoo biome. Pp 50-69. In: Cowling, R.M. \& P.W. Roux (eds.). The karoo biome: a preliminary synthesis. Part 2-vegetation and history. Pretoria: Council for Scientific and Industrial Research, National Scientific Programmes Unit. (South African National Scientific Programmes report; no. 142.)

VAN DER WALT, P.T. 1980. A phytosociological reconnaissance of the Mountain Zebra National Park. Koedoe 23: 1-32.

WALKER, B.H. 1976. An approach to the monitoring of changes in the composition and utilization of woodland and savanna vegetation. South African Journal of Wildlife Research 6: 1-32.

WATSON, L.H. 1997. The feeding ecology of eland in Mountain Zebra National Park. PhD thesis, University of the Witwatersrand, Johannesburg.

ZAR, J.H. 1984. Biostatistical analysis. New Jersey: Prentice Hall. 